\title{
The Effects of Human Capital on the Total Quality Management: High Technology Sectors
}

\author{
Houneida Ben Brahim \\ Assistant Professor in Accounting \\ Faculty of Business Administration \\ University of Tabuk - Saudi Arabia \\ E-mail: ben_brahim_houneida@yahoo.com \\ Slim Hadoussa \\ Assistant Professor in Management Information System \\ Faculty of Business Administration \\ University of Tabuk - Saudi Arabia \\ E-mail: slim.hadoussa@gmail.com
}

Received: April 2, $2018 \quad$ Accepted: April 30, $2018 \quad$ Published: July 1, 2018

doi:10.5296/jmr.v10i3.13103ＵRL: https://doi.org/10.5296/jmr.v10i3.13103

\begin{abstract}
The firms should place quality at the top of its strategic priority if they want to survey and attain competitive advantage. Among the most effective quality techniques that have been verified by several organizations from several sectors and countries, there is the Total Quality Management (TQM) technique. Besides, literature indicates that human capital is considered as the substantial source of growth and organizational sustainability of companies. In this sense, this study seeks to investigate the effect of human capital on the achievement of TQM. A questionnaire survey was developed and distributed to a sample of 146 employees working in companies installed in Tabuk region in Saudi Arabia. SPSS software program was used for statistical data analysis. Results showtwo critical success factors of TQM which are the cooperative and supportive leadership, and the employees' job satisfaction.
\end{abstract}

Keywords: Total Quality Management, human capital, leadership, knowledge, employees' job satisfaction 


\section{Introduction}

The intensive competition in the business environment has led to significant changes in the philosophy of conduct in an organization and achievement of a competitive advantage. For this reason, provision of a higher quality service has become a strategic imperative for organizations to satisfy their customer's needs and expectations. So, firms should place quality at the top of its strategic priority if they want to survey and attain competitive advantage (the quality may be recognized by the ISO certification or by its reputation for example). Thus, it is obvious to consider the quality among the strategic tools for measuring business performance. Among the most effective quality techniques that have been verified by several organizations from several sectors and countries, there is the Total Quality Management.

Korankye (2013) has defined TQM as "a method that attempts to improve performance and quality to satisfy customer expectations. This can be attained by combining and linking all quality related functions and processes throughout the organization. TQM takes a holistic view of all quality measures employed by an organization". Furthermore, TQM seeks to prevent failures before being made. So, it is not merely to find failures induced by employees, but to remove the causes of failure to help people to do a better job with less cost, to improve quality, and to increase output.

More recently, Chao et al .(2015) define TQM as " a management philosophy which is often applicable when working to improve quality across different cultures". Quality concerns not only the product or services but it is a multi-dimensional construct which must be managed.

Despite the large number of works on this area, TQM remains an ambiguous concept. As indicated by Gharakhani and al (2013), this may be due to the fact that 'the term TQM means different things to different people'.

In general, the most of definitions insist that the prerequisite of the TQM is an appropriate human capital. The companies must motivate their employees to participate with the others in competition to share their innovative ideas. The human capital may be defined as an amalgamation of skills, knowledge, talent and experience of employees which may provide to the firm's added value and sustainable development (Ding and Li, 2010). Besides, literature indicates that human capital is considered as the substantial source of growth and organizational sustainability of companies. In this sense, this study seeks to investigate the effect of the human capital on the achievement of TQM. This study is very important because there is little consensus about precisely what it is that organization must do in order to achieve business excellence through TQM and identify appropriate critical success factors.

\section{Motivation}

Employees' quality is a very important element but most firms ignore it. Indeed, because most firms ignore the fruitfulness of training and the development of their employees, inferior goods are produced by them. Thence, employee participation in quality improvement must be recognized, supported, and acknowledged. Employees should have a positive attitude towards the quality management initiative 
This study has important implications for managers. It motivates managers to invest in human capital and to achieve business excellence through TQM.

Not only the employees are responsible for the success of their firms but, also the leaders and their aptitude for the development and the change of their business environment. The style of the leadership is primary imperative for the success of any adopted strategy and any chosen tools.

\section{Literature review}

In today's globally competitive environment, human capital (both managers and employees) is vitally important for the organisation's success. Human capital is an intangible resource. Indeed, firm includes both tangible and intangible resources. Tangible resources are not rare, it is easy to access and purchase in the open market. Nevertheless, according to the resource-based view, only intangible resources can be source of competitive advantage due to their characteristics and their influence on the firm performance. Due to these resources, firm differentiate itself in terms of costs and quality of products and services.

Through its development and optimal exploitation, human resources may be strategic resources and, consequently, source of competitive advantage. In this sense, Ben Brahim and Ben Arab (2011), have demonstrated not only that intangible resources including human resources constitute source of competitive advantage, but also a principle factor for sustainability of this competitive advantage and realization of specific profit (Figure 1).

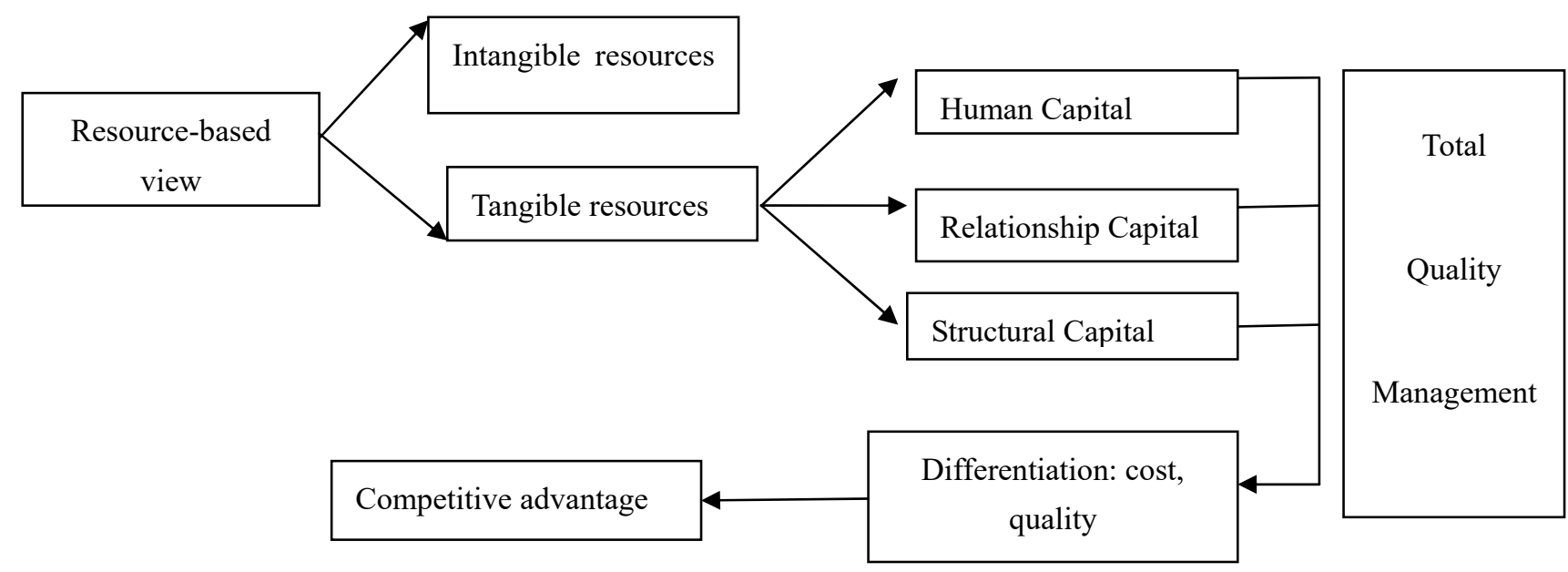

Figure 1. Research Model - adopted from Ben Brahim and Ben Arab (2011)

According to the literature review, most researches have focused on studying the effect of TQM on the financial and operational performance of organization in different countries (Hsu and Chen, 2013). Also, many studies were focused on the relationship between TQM and innovation performance, despite not enough researches that were conducted on the topic of how organizations should implement fruitful TQM on in other words, how organizations should operate to really succeed its strategy. Studies on the topic of the effect of human capital on TQM practices were scattered and dispersed. So, it is important to investigate this 
issue in unexplored contexts.

Also, human capital constitutes the unique and valuable resource which can be accumulated by the firm. According to Mehdi and al. (2014) and Kenget and al. (2005), the implementation of TQM depends on optimal use of people and resources by managers which transposes on strong relationship between employees and customers satisfaction due to optimal implication of employees in the production process.

Empirical studies have shown that the way with which firms implement TQM affects the financial and operating performance. The study of Mohammed and al. (2014) shows how to improve operational performance using TQM in one of the largest Saudi telecommunication company by using only correlation analysis. Their results are consistent with previous studies in the literature review that there is a positive relation between operational performance and TQM practices.

The TQM is not only a management tool for providing quality products and services but also a process that leads to increased productivity and more favourable competitive position. But, only proper TQM implementations can lead to a better competitive advantage.

Many studies have investigated barriers to successful TQM implementation (Khan, 2011). These studies have found that poor management practices contributed to the failure of TQM initiatives. Alsughayir (2014) confirmed that the most considerable barrier to TQM is employees' resistance to change. Also, he found that lack of motivation constitutes another potential barrier to TQM. Organizations which do not provide a motivating work environment, may lose the best employees to other organizations that offer more attention and appreciation to the employees. Therefore, there are preconditions for achieving the fixed objectives of TQM. These preconditions differ from one organization to another. Thus, this crucial issue should be more reprocessed in different contexts.

\section{Hypotheses}

TQM practices depend on a certain set of values and beliefs shared by all organisations such as the style of leadership applicable in the organization. Indeed, the leader may influence the employees to become willing followers in the achievement of organizational goals.As such, the responsibility of leaders consists of creating and maintaining the internal environment in which employees are able to become completely involved in achieving the organization's goals and aims. For this reason, Leadership has been considered as a key driver for the successful TQM efforts and, then, increasing the financial and operating performance. Leadership represents one dimension of the investment in human capital. The following hypothesis were postulated and tested:

Hypothesis 1: The degree of implementation of total quality management practices is positively associated with the cooperative leadership.

According to Khalique and al. (2011), human capital includes abilities, skills and knowledge possessed by the employees of the organizations to contribute in the sustainable development and long-term survival. In fact, with the high advanced technology, nowadays organizations 


\section{Macrothink}

Journal of Management Research

ISSN 1941-899X 2018, Vol. 10, No. 3

were obliged to use advanced techniques for providing products or services. Consequently, organizations will need more number of employees with high qualification in terms of knowledge and skills. Thus, any initiatives of quality improvement throughout any strategy will depend on the qualification of the employees. So, the following two hypotheses are posited:

Hypothesis 2: The degree of implementation of total quality management practices is positively associated with employees' knowledge.

Hypothesis 3: The degree of implementation of total quality management practices is positively associated with employees' skills.

Also, The effectiveness of an organization depends on the extent to which employees perform their roles and move towards the corporate goals and objectives. According to Chin and Saudah (2011), employee job satisfaction represents a central factor of an organization's growth and success. Job satisfaction reflects the emotional reaction to the employee's job perception. It is considered as a factor that affects the employee performance and, consequently, the achievement of the TQM. Then, the fourth hypothesis formulated:

Hypothesis 4: The degree of implementation of total quality management practices is positively associated with employees' job satisfaction.

\section{Methodology}

\section{Sample and data collection}

A questionnaire survey was developed and distributed to a sample of 180employees working in companies installed in Tabuk region in Saudi Arabia.146 responds were taken in consideration after eliminating none serious responds in order to preserve the reliability of our empirical results.

According to Korankye (2013) high technology service firms is considered and manufacturing firms is taken away because TQM principles, tools and techniques differfrom one sector to another. The most notable characteristics of the service firms is the intangibility of their output (services) as compared to tangible product in manufacturing firms (Ben Brahim and Ben Arab, 2011). Then, our sample is composed by companies from services sector detailed as follows: 
Table 1. Sample description

\begin{tabular}{lll}
\hline Sectors & Responds' Numbers & Percentage \\
\hline Telecommunications & 62 & $43 \%$ \\
\hline Sales of high technology products & 37 & $25 \%$ \\
\hline Medical services & 47 & $32 \%$ \\
\hline Total & 146 & $100 \%$ \\
\hline
\end{tabular}

In this study, the questionnaire consists of two parts. The first part contains a general information regarding age, educational level and years of experience. The second part developed to measure the relationship between the human capital and the TQM was formed in accordance with dimensions. They are respectively as follows: TQM, Leadership, Knowledge, Skills, and employee Job Satisfaction.

Likert scale are used to measure respondents' attitudes to a particular questions as follows:1strongly disagree, 2- disagree, 3- neutral, 4- agree, 5- strongly agree.

SPSS software program was used for statistical data analysis.

\section{Results and Discussion}

\section{Empirical results and interpretations}

\section{Exploratory Factor Analysis}

This paragraph examines the appropriateness of factor analysis as a method of data reduction as shown in table 2:

Table 2. Exploratory Factor Analysis and Reliability levels of instruments

\begin{tabular}{|c|c|c|c|c|c|c|}
\hline Factors & $\begin{array}{l}\text { Number } \\
\text { questions }\end{array}$ & of & KMO & Eigenvalue & $\begin{array}{l}\text { Variance } \\
\text { explained (\%) }\end{array}$ & $\begin{array}{l}\text { Cronbach's } \\
\text { Alpha }\end{array}$ \\
\hline TQM & 19 & & 0,922 & 6,1 & 61,4 & 0,929 \\
\hline Leadership & 12 & & 0,903 & 4,9 & 61,3 & 0,908 \\
\hline Knowledge & 10 & & 0,862 & 4,3 & 70,2 & 0,914 \\
\hline Skills & 10 & & 0,902 & 4,4 & 55,2 & 0,895 \\
\hline Satisfaction & 10 & & 0,858 & 3,5 & 59,4 & 0,862 \\
\hline
\end{tabular}




\section{Ml Macrothink}

The Kaser-Mayer-Olkin (KMO) is a measure of the sampling adequacy. It can signal in advance whether sample size is large enough to reliably extract factors. This measure varies between 0 and 1 and values closer to 1 are better. According to the table, values of KMO) obtained from this study are between 0,858 and 0,922 , so it shows that sample size is sufficient.

Bartlett's test of Sphericity tested the null hypothesis and found that the correlation matrix is an identity matrix within which all correlations equal to zero. According to the table, Bartlett test result shows that $\mathrm{p}<0,01$. Therefore, the null hypothesis rejected and the alternate hypothesis is accepted, that says that there may be statistically significant interrelationship between items. Thus, these tests indicate the suitability of our data for structure detection.

After determining the suitability of data set, the next step is to test the reliability of the measurement. The Cronbach's coefficient Alpha value is the most widely used statistics to determine the reliability of the measurement. The result of Cronbach's Alpha value for all factors is between 0.929 and 0,862 , which are excellent range and indicates the reliability of data for measurement parameters.

\section{Multiple Linear Regression Analysis}

Before the multiple linear regression analysis, correlation coefficient was used to describe the association between TQM practices and Human Capital as shown in table 3.

Table 3. Correlation of factors

\begin{tabular}{llllll}
\hline Variables & $\mathbf{1}$ & $\mathbf{2}$ & $\mathbf{3}$ & $\mathbf{4}$ & $\mathbf{5}$ \\
\hline Leadership & 1 & & & & \\
\hline Knowledge & $0.441^{*}$ & 1 & & & \\
\hline Skills & 0.166 & 0.286 & 1 & & \\
\hline Job Satisfaction & $0.522^{* *}$ & $0.48^{*}$ & $0.482^{*}$ & 1 & \\
\hline TQM & $0,696^{* *}$ & $0.414^{*}$ & 0.281 & $0.628^{* *}$ & 1 \\
\hline
\end{tabular}

** coefficient is significant at the $\mathrm{p}<0.001$ levels

* coefficient is significant at the $\mathrm{p}<0.05$ levels

As the correlation matrix highlights TQM practices were positively and significantly linked to Leadership and employee job satisfaction, but less important to the knowledge. These results may be explained essentially by the fact that the cooperative Leadership and the 
employee Job Satisfaction provide favorable terrain to achieve successful TQM implementation.

Between the independent variable (TQM) and the dependent variables (Leadership, Knowledge, Skills and Job Satisfaction), the correlation coefficients were less than 0.9, demonstrating that our data was not affected by a collinearity problem (Hair et al., 2006), and consequently performed safely our Multiple Linear Regression.

In the first time, Multiple Linear Regression were carried out to comprehend the link between the human capital and the degree of successful TQM implementation. The results are summarized in table4.

Table 4. Results of Regression Analysis between TQM practices and Human Capital

\begin{tabular}{llll}
\hline Variables & Beta & t-value & sig \\
\hline Leadership & 0,504 & 7,55 & 0,000 \\
\hline Knowledge & 0,015 & 0,228 & 0,82 \\
\hline Skills & 0,006 & 0.089 & 0,92 \\
\hline Job Satisfaction & 0,351 & 4,712 & 0,000 \\
\hline
\end{tabular}

Overall model $\mathrm{F}=48,026 ; \mathrm{p}<0.001 ; \mathrm{R}^{2}=0.575 ;$ Adjusted $\mathrm{R}^{2}=0.563$

Independent variable: TQM (Total Quality Management)

Dependant variables: Leadership, Knowledge, Skills, Job satisfaction

The empirical results point to a significant impact of the cooperative leadership on the successful TQM implementation with highest coefficient value $(\beta=0,504 ; \mathrm{t}=7,55 ; \mathrm{p}<$ $0,001)$. Thus, the first hypothesis is fulfilled. This variable includes several crucial points in the questionnaire such as:

- The direction have a clear vision of the human capital's concept.

- The direction takes care of the increase and development of the skills, and efficiency of human resources since their appointment and until the end of their carriers.

- The direction believes that training is the best way to gain the practical skills of human resources.

- $\quad$ No sudden departure for workers.

- The direction publishes and announces excellent works of their employees and reward them in front of all members of the company.

- The leaders involve the employees in their decisions 
These findings provide practical insights into the role of the cooperative and supportive leadership on the realisation of the TQM. Otherwise, cooperative and good leadership is essential in order to improve quality across the organization, as the leading force that sets objectives and assists employees to implement these objectives.

In this sense, Porciuncula and Rosario (2013) consider that leadership is the key driver for successful TQM effort. Also, Arwa and al. (2012) indicate leaders as developers and facilitators of the achievement of the mission and adopted vision. Indeed, TQM consists of all activities that managers perceive and perform to improve their quality. But, Maiya (2014) recommends that organizations should increase investments in leadership development, as an investment in human capital, in order to improve operational effectiveness of the whole firms. Empirically, he finds that leadership training programs have an effect on behavioral outcomes at the individual level (such as self-awareness). At the organizational level, the researcher proves that leadership development program influence positively on the sales outcomes of the firms through fulfillment of costumer expectations. Therefore, results suggest that training programs on TQM should be regularly organized for staff of organizations so as to ensure that the best practices of TQM are implemented if they want to achieve a sustainable competitive advantage.

The empirical examination of the relationship between TQM and the knowledge and skills integrated in the human capital has not concluded a significant impact. Thus, $\mathrm{H}_{2}$ and $\mathrm{H}_{3}$ are rejected. These two latter factors don't have the power and the exception to enhance business excellence through TQM. So, these findings may be explained by the fact that the requirement of knowledge and skills is an evidence for the recruitment of the employees.

For the validation of $\mathrm{H}_{4}$, results show a strong and positive effect between employees' Job Satisfaction and the realisation of TQM $(\beta=0,351 ; \mathrm{t}=4,712 ; \mathrm{p}<0,001)$. So, hypothesis $\mathrm{H}_{4}$ is accepted. Our findings confirmed what is said by Joiner (2006), That: "if employees do not feel there is acknowledgment and support from the organisation and from work colleagues, then implementation of TQM programs may be sub-optimal."

More clearly, our variable job satisfaction includes a total of 10 questions reflect essentially:

- The degree of satisfaction felt towards the top management, the work, co-workers;

- The degree of the cooperation and communication within the organization in different levels;

- $\quad$ The degree of the citizenship field by the employee;

- The degree of the employee empowerment reflecting the individual freedom assigned with responsibility.

- $\quad$ The importance of the monetary and non-monetary compensations.

Indeed, every employee should develop an attitude to improve the quality of the organization. This attitude may be acquired through provision of their feeling of satisfaction. Job satisfaction includes several pivotal elements such as open communication, teamwork and 
collaboration, easy access to the information, appropriate training, incentives programs in order to ensure service quality. In this sense, several researches indicate that compensation systems are considered as one of the best incentives to motivate employee to improve quality, creativity, innovation, outcomes (Johnson and al., 2015, Gupta and Shaw, 2014) and to increase the probability of sustained success. Then, employees should be managed properly and motivated by offering the best remuneration and compensation. When an employee has a job satisfaction, this feeling will be translated to improved task completion and customer service. Employee satisfaction can result in customer satisfaction. Satisfied employees are more likely to work harder and provide better services and enhance organizational performance.

Also, managers should enhance free margin for thinking through, giving them more job autonomy. Consequently, employees will have a chance to make their own best way of doingtheir jobs. Through job satisfaction, organizations may build "organizational citizenship behaviour".

The results approval is based on the Partial Least Squares regression.

\section{PLS regression (Partial Least Squares regression)}

In the second time, PLS regression was carried out in order to confirm our empirical results. PLS regression is a technique that generalizes and combines features from principal component analysis and multiple regression. It is especially useful to predict a set of dependent variables from a large set of independent variables (used for manipulating eigenvectors). This approach is less restrictive in terms of normal distributions variables and error terms. This approach is recommended to make prediction.

As shown in the table 5, the results of PLS regression confirms the previous findings.

Table 5. PLS regression

\begin{tabular}{llll}
\hline Latent variables & Path coefficient & t-value & $\operatorname{Pr}>|\mathbf{t}|$ \\
\hline Leadership & 0,5038 & 7,5639 & 0,000 \\
\hline Knowledge & 0,0213 & 0,3311 & 0,741 \\
\hline Skills & 0,0266 & 0,4243 & 0,672 \\
\hline Satisfaction & 0,3420 & 4,5664 & 0,000 \\
\hline
\end{tabular}

Overall model $\mathrm{F}=49,119 ; \mathrm{p}<0.001 ; \mathrm{R}^{2}=0.5822 ;$ Adjusted $\mathrm{R}^{2}=0.5734$ 


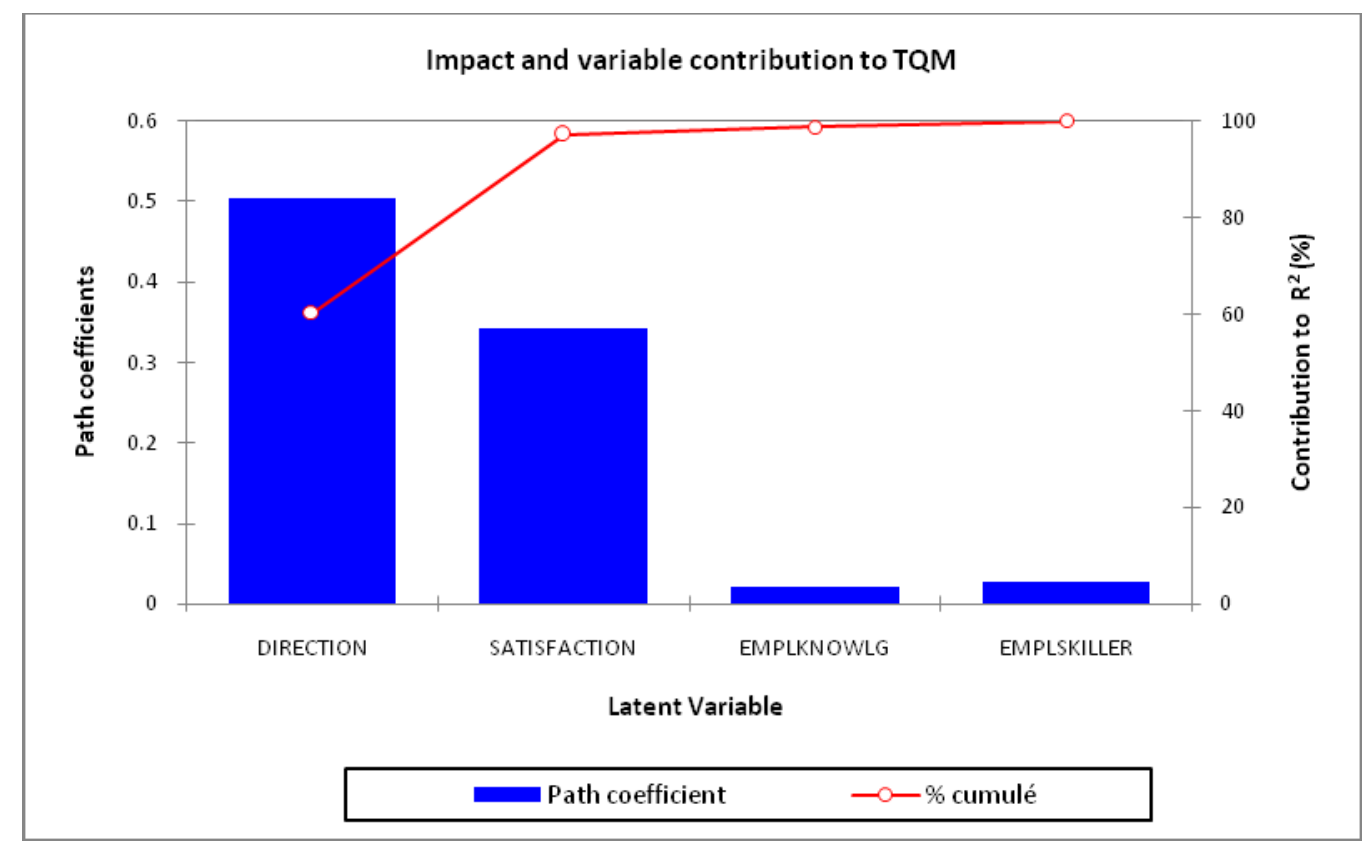

Figure 2. Impact and variable contribution to TQM

\section{Conclusion}

In an era described by rapid and continuous change, one of the management approach that can be used to achieved continuous quality improvement is total quality management.

Results highlight two critical success factors of TQM which are the cooperative Leadership and the employees Job Satisfaction. In fact, The quality needs to be understood at the same way between managers and employees from every level in the company. TQM begins with the prerequisite that managers and employees must cooperate with each other in order to achieve quality for the needs of the customer. Otherwise, the Implementation of the TQM will be difficult.

Our findings could encourage top management in Saudi organization to review their strategy via employees. Managers should give more attention to the employees in designing their strategy. Indeed, Any initiatives of improvement which are taken by management cannot be fruitful without implication of employees.

Managers would get a higher level of employee job satisfaction. They should remove feelings of fear by assuring job security, developing a common vision, and motivating employees by utilising various monetary and non-monetary incentives to reward superior performance (Kabir and Parvin, 2011). Tension between management and employees increases the risk of failure of TQM implementation.

There are several limitations to this study. First, the study was conducted only in Tabuk consequently the attitude of the employees may be different in other cities in Saudi Arabia. Plus, the manager's demeanor in conducting organizations may be different in accordance with characteristics of the region, nationality of employees, social factors, etc. Second, despite the provided efforts in collecting data in this region, the response rate was modest. 
Then, this study may encounter a problem of generalizability.

\section{References}

Alsughayir, A. (2014). Barriers to TQM implementation within a private medical services organization in Saudi Arabia. International Journal of Business Administration, 5(3), 117-121. https://doi.org/10.5430/ijba.v5n3p117

Arwa, A., Nedal, F., \& Bana, A. (2012). The application of quality management in financial services sector in Jordan. Problems and Perspectives in management, 10(3), 112-124.

Chao, C.Y., Hsu, H.M., Hung, F.C., Lin, K.H., \& Liou, W. (2015). Total quality management and human resources selection: A case study of national teacher selection in Taiwan. Total Quality Management \& Business Excellence, 26(2), 157-172. https://doi.org/10.1080/14783363.2012.733261

Chin, K., \& Saudah, S. (2011). The impact of human capital and total quality management on corporate performance. Journal of Contemporary Research in Business, 3, 1091-1100.

Ding, Y., \& Li, G. (2010). Study on the management of intellectual capital. International Journal of Business and Management, 5(2). https://doi.org/10.5539/ijbm.v5n2p213

Gharakhani, D., Rahmati, H., Farrokhi, M.R., \& Farahmandian, A. (2013). Total Quality Management and organizational performance. American Journal of Industrial Engineering, 1(3), 46-50.

Gupta, N., \& Shaw, J.D. (2014). Employee compensation: The neglected area of HRM research. Human Resource Management Review, 24(1), 1-4. https://doi.org/10.1016/j.hrmr.2013.08.007

Hair, J.B., Babin, B., Anderson, R., \& Tatham, R. (2006). Multivariate data analysis, New Jersey: Upper Saddle River, Perarson Education, Inc.

Ben Brahim, Houneida, \& Ben Arab, Mounira. (2011). The efficience of accounting Normalization in the matter of intangible: Asset versus Expense. International Journal of Accounting and Financial Reporting, 1(1), 72-98. https://doi.org/10.5296/ijafr.v1i1.762

Hsu, H.L., \& Chen, Y.L. (2013). The effects of total quality management and organizational learning on business performance: Evidence from Taiwanese insurance industries. Journal of Total Quality Management, 51, 86-97.

Johnson, J.S., Friend, S.B., \& Agrawal, A. (2015). Dimensions and contingent effects of variable compensation system changes. Journal of Business Research, 69(8), 2923-2930. https://doi.org/10.1016/j.jbusres.2015.12.061

Kabir, M.N., \& Parvin, M.M. (2011). Factors affecting employee job satisfaction of pharmaceutical sector. Australian Journal of Business and Behavioral Sciences, 213, $1000-1007$

Khalique, M., Shaari, J.A., \& Isa, A.H. (2011). Intellectual capital and its major components. 
International Journal of Current Research, 3(6), 343-347.

Keng, B., Baker, N., Arumugam, A., Vellapan, L., \& Loke, A. (2005). Does TQM influence employees' job satisfaction? An empirical case analysis. International Journal of Quality \& Reliability Management, 24(1), 62-77.

Khan, M. (2011). An empirical study of barriers in implementing Total Quality Management in service organizations in Pakistan. Asian Journal of Business Management, 2(4), 155-161.

Korankye, A. (2013). Total Quality Management: A source of competitive Advantage. A comparative study of manufacturing and service firms in Ghana. International Journal of Asian Social Science, 3(6), 1293-1305.

Maiya, V.T. (2014). The effect of leadership development program on behavioral and financial outcomes: Kazakhstani experience, Procedia - Social and behavioral.

Mehdi, N., Elham, T., Maral, K., \& Farzaneh, S. (2014). The impact of organizational citizenship behavior on enterprise resource planning success: the mediator role of TQM. International Journal of Quality \& Reliability Management, 31(1), 53-65.

Mohammed, A., Alharthi, A.M., Alharthi, D.K., and Saleh, W., 2014, Organization performance improvement using TQM. International Journal of Computer Applications, 10(9), 29-33. https://doi.org/10.5120/18942-0361

Porciuncula, M.L., \& Rosario, L.M. (2013). Interrelation of Total Quality Management, Human Capital, Training, and Organizational Performance, https:/www.pomsmeetings.org/confpapers/052/052-0218.pdf 